\title{
Predominant Expression of Platelet-Activating Factor Receptor in the Rat Brain Microglia
}

\author{
Mikiro Mori, ${ }^{1}$ Makoto Aihara, ${ }^{1}$ Kazuhiko Kume, ${ }^{1}$ Makoto Hamanoue, ${ }^{2}$ Shinichi Kohsaka, ${ }^{2}$ and Takao Shimizu ${ }^{1}$ \\ ${ }^{1}$ Department of Biochemistry, Faculty of Medicine, The University of Tokyo, Tokyo 113, Japan, and '2Department of \\ Neurochemistry, National Institute of Neuroscience, Kodaira, Tokyo 187, Japan
}

Cellular localization of platelet-activating factor (PAF) receptor in the rat brain was determined by (1) in situ hybridization, (2) Northern blot analysis in primary cell cultures of neurons, microglia, astrocytes, and fibroblasts, and (3) $\mathrm{Ca}^{2+}$ imaging in hippocampal culture. In situ hybridization revealed that the PAF receptor mRNA is expressed intensely in microglia and moderately in neurons. Northern blot analysis revealed that PAF receptor $\mathrm{mRNA}$ is the most abundant in microglia. In primary hippocampal cultures, PAF elevated intracellular $\mathrm{Ca}^{2+}$ concentration in microglia and also in neurons, but to a lesser extent.
These results suggest predominant presence of PAF receptor in microglia. Cultured microglia also expressed $\mathrm{cPLA}_{2}$ mRNA the most intensely. PAF-activated microglia released arachidonic acid in a $\mathrm{Ca}^{2+}$-dependent manner and without conversion to its derivatives. We propose that microglia as well as neurons contribute to PAF-related events in the CNS by releasing arachidonic acid.

Key words: platelet-activating factor; PAF; receptor; mRNA; microglia; in situ hybridization; $\mathrm{Ca}^{2+}$ imaging; arachidonic acid
Platelel-activating factor (PAF) (1-O-alkyl-2-acetyl-sn-glycero-3phosphocholine) was characterized originally as a potent activator of platelets; its actions include aggregation, morphological changes, and granule secretion (Benveniste et al., 1979; Blank et al., 1979; Demopoulos et al., 1979). This lipid mediator was shown later to have diverse biological effects on various cells and tissues (Hanahan, 1986; Braquet et al., 1987; Snyder, 1989; Prescott et al., 1990; Izumi and Shimizu, 1995). In the CNS, PAF is involved in various events (Feuerstein et al., 1990; Frerichs and Feuerstein, 1990; Doucet and Bazan, 1992; Bazan, 1994). This factor is produced in the nervous system through application of acetylcholine (Sogos et al., 1990), dopamine (Bussolino et al., 1986), or convulsant electrical stimuli (Kumar et al., 1988). PAF receptor (PAFR) (Honda et al., 1991; Bito et al., 1994) is present functionally in brain tissues (Bito et al., 1992); PAFR antagonists suppress postischemic neuronal injury (Panetta et al., 1989; Gilboe et al., 1991; Prehn and Krieglstein, 1993). It is also related to human immunodeficiency virus (HIV)-associated neuronal cell death (Genis et al., 1992; Epstein and Gendelman, 1993; Gelbard et al., 1994; Lipton, 1994; Lipton et al., 1994). It enhances excitatory synaptic transmission (Clark et al., 1992), induces long-term potentiation (LTP) in the hippocampus (Wieraszko et al., 1993; Kato et al., 1994), and increases memory test performance (Izquierdo et al., 1995). It activates intracellular signaling cascades such as phosphoinositide turnover (Murphy and Welk, 1990; Yue et al., 1992;

\footnotetext{
Reccived Nov. 3, 1995; revised March 13, 1996; accepted March 15, 1996.

This work was supported in part by a Grant-in-Aid from the Ministry of Education, Science, and Culture and the Ministry of Health and Welfare of Japan and by grants from the Naito Foundation, the Yamanouchi Foundation, and the Human Science Foundation. We thank Dr. N. Ishizuka, Tokyo Metropolitan Institute of Neuroscience, for comments; Dr. Y. Kudo, Tokyo College of Pharmacy, for helpful suggestions; and Dr. M. Ohara for comments and critical reading of this manuscript.

Correspondence should be addressed to T. Shimizu, Department of Biochemistry, Faculty of Medicine, The University of Tokyo, 7-3-1 Hongo Bunkyo-ku, Tokyo 113, Japan.

Dr. Mori's present address: Department of Ophthalmology, Faculty of Medicine, The University of Tokyo, 7-3-1 Hongo Bunkyo-ku, Tokyo 113, Japan.

Copyright (c) 1996 Society for Neuroscience $0270-6474 / 96 / 163590-11 \$ 05.00 / 0$
}

Petroni et al, 1994), rise in intracellular $\mathrm{Ca}^{2+}$ concentration $\left(\left[\mathrm{Ca}^{2+}\right]_{\mathrm{i}}\right.$ ) (Kornecki and Ehrlich, 1988, 1991; Willard, 1992; Yue et al., 1992), and immediate-early gene expression (Squinto et al., 1989). More recently, PAF has been shown to play a role in the development of the CNS, because a subunit of PAF acetylhydrolase, a PAF-inactivating enzyme, has 99\% homology with the protein encoded by the gene causing Miller-Dieker lissencephaly, a disorder characterized by the absence of gyri and sulci in the cerebral cortex (Reiner et al., 1993; Hattori et al., 1994).

Our previous study (Bito et al., 1992) showed that PAFR is expressed ubiquitously in the rat brain and functions in both neurons and non-neuronal cells in hippocampal cultures. Other studies showed that cultured astrocytes (Petroni et al., 1994) and microglia (Rhigi et al., 1995) respond to PAF. Thus, we assumed that PAFR in glia takes part in the PAF-related events in the CNS. In the present study, we attempted to localize PAFR in identified cell types of the rat brain by combining in situ hybridization and immunohistochemistry. We then identified PAF-responsive glial cells in primary hippocampal cultures by measurement of PAF-elicited rise in $\left[\mathrm{Ca}^{2+}\right]_{i}$, followed by immunocytochemistry. We subsequently characterized PAFinduced release of arachidonic acid from microglia, which we found express the largest amount of PAFR mRNA. Our findings suggest a possible contribution of microglia to the PAFrelated events in the CNS.

\section{MATERIALS AND METHODS}

In situ hybridization. Sprague-Dawley rats (male, $\sim 250 \mathrm{gm}$ ) were anesthetized deeply with diethyl ether and decapitated. Brains were removed quickly, dissected coronally or parasagittally, embedded in OCT compound, and frozen in isopentane at $-30^{\circ} \mathrm{C}$. Ten-micrometer-thick coronal and parasagittal sections were made on a cryostat, thaw-mounted on poly-L-lysine (PLL)-coated slide glass, and air-dried for $10 \mathrm{~min}$ at room temperature. The sections were fixed in $4 \%$ paraformaldehyde buffered with $0.1 \mathrm{M}$ phosphate buffer for $10 \mathrm{~min}$, acetylated with $0.25 \%$ acetic anhydride, dehydrated in ethanol of ascending concentrations $(70 \%$, $95 \%, 100 \%$, and $100 \%$ ), and stored at $-80^{\circ} \mathrm{C}$ until use. Sections of rat 
whole embryos, embryonic day 18 (E18), and pup brains (P0, P7, P14, and P21) were prepared in the same procedures.

In situ hybridization was carried out as described previously (Shigemoto et al., 1992), with several modifications. Briefly, a $P v u I$-AvaI fragment $(0.9 \mathrm{~kb})$ of the coding region of rat PAF receptor cDNA (Bito et al., 1994) was subcloned into pBluescript II (Stratagene, La Jolla, CA) and linearized by $B a m \mathrm{HI}$ digestion. A ${ }^{35} \mathrm{~S}$-labclcd cRNA probe was made with a cRNA synthesizing kit (Maxiscript, Ambion, Austin, TX). The final radioactivity of the probe solution was adjusted to $10^{5} \mathrm{cpm} / \mu \mathrm{l}$. After hybridization at $55^{\circ} \mathrm{C}$ for $6 \mathrm{hr}$ in a humid chamber, the sections were washed in $2 \times \mathrm{SSC}$ at room temperature overnight and in $2 \times \mathrm{SSC}$ at $60^{\circ} \mathrm{C}$ for $1 \mathrm{hr}$, and they were treated with RNase $\mathrm{A}(20 \mu \mathrm{g} / \mathrm{ml})$ at $37^{\circ} \mathrm{C}$ for 30 $\min$ in $0.5 \mathrm{M} \mathrm{NaCl} / 10 \mathrm{~mm}$ Tris-Cl$/ 1 \mathrm{~mm}$ EDTA. The final wash was carried out in $0.1 \times \mathrm{SSC}$ at $67^{\circ} \mathrm{C}$ for $1 \mathrm{hr}$. The sections were dehydrated in ethanol of ascending concentrations ( $30 \%, 90 \%, 100 \%$, and $100 \%$ ). The air-dried sections were autoradiographed on Hyperfilm- $\beta \max$ (Amersham, Buckinghamshire, UK) or dipped in 1:1 diluted NTB-2 emulsion (Kodak, Rochester, NY). The exposure periods were $10 \mathrm{~d}$ for the film and 67 weeks for the emulsion. The hybridization signals were evaluated by counting the number of silver grains per cell in the sections processed in the same procedures.

Immunohistochemistry followed by in situ hybridization. To identify the most intensely labeled cells, the brain sections from adult rats were immunostained with a macrophage/microglia marker (OX-42, anti-CR-3 complement receptor antibody) or an astrocyte marker [antiglial fibrillary acidic protein (GFAP) antibody] before in situ hybridization. OX-42 (Serotec, Oxford, UK) and anti-GFAP antibody (G-3893, Sigma, St. Louis, MO) were affinity-purificd twice with protein-G columns (Pharmacia, Uppsala, Sweden), because incubation with the crude antibodies substantially decreased mRNA signals of the subsequent in situ hybridization.

Cryostat sections ( $10 \mu \mathrm{m}$ thick) of adult rat brains were fixed serially in $4 \%$ paraformaldehyde buffered with $0.1 \mathrm{M}$ phosphate buffer, $50 \%$ aqueous acetone, $100 \%$ acetone, and $50 \%$ aqueous acetone (each for $2 \mathrm{~min}$ ), and blocked with $0.1 \%$ nuclease-free bovine serum albumin (BSA) (Sig$\mathrm{ma}$ ) in PBS for $5 \mathrm{~min}$ at room temperature. Incubation with the purified primary antibodies $(1: 200)$ was carried out for $10 \mathrm{~min}$ at room temperature with $0.1 \%$ BSA/PBS. After three brief washes with PBS, the sections were incubated with biotinylated anti-mouse IgG antibody (1:200; Vector, Burlingame, $\mathrm{CA}$ ) with $0.1 \% \mathrm{BSA} / \mathrm{PBS}$ for $10 \mathrm{~min}$ and subsequently with avidin-biotin-horseradish peroxidase complex (Vectastain Elite; Vector) for $10 \mathrm{~min}$, according to the manufacturer's instructions. Immunostaining was visualized with $1 \mathrm{mg} / \mathrm{ml}$ diaminobenzidine tetrahydrochloride $(D A B)$ in PBS containing $0.02 \% \mathrm{H}_{2} \mathrm{O}_{2}$. The stained sections were then acetylated, dehydrated, and subjected to in situ hybridization, as described above. All of the immunostaining procedures were carried out under RNase-free conditions.

Primary cell culture. Microglial cells were prepared from a primary culture of neonatal rat cerebral tissue, as described previously (Nakajima et al., 1989, 1992). The purity of microglia was estimated to be $>99 \%$ (data not shown) by staining with fluorescein isothiocyanate (FITC)labeled isolectin $\mathrm{B}_{4}$ (Sigma).

Neurons were prepared from embryonal (E16) rat neocortical tissues as described previously (Takci ct al., 1991). The purity of neuronal cells was estimated to be $>99.5 \%$ (data not shown) by staining with two monoclonal antibodies against neurofilament and microtubule-associated protein 2 (MAP2) (Serotec).

Astrocytes were prepared from the brain of rat pups (P3) by the previously described method (Mori et al., 1990), with modifications. Nonastroglial cells were removed by shaking (MaCarthy and de Vellis, 1980) and subculturing twice. The final purity of astrocytes was estimated to he $>99.5 \%$ (data not shown) by staining with anti-GFAP antibody. The maturity of neurons and astrocytes was confirmed by immunoreactivity of neurofilament/MAP2 and GFAP, respectively.

Fibroblasts were prepared from pooled meninges of neonatal rat brains, as described previously (Saitoh et al., 1992). The purity of fibroblastic cells was estimated to be $>90 \%$ from the staining with anti-human fibronectin antiserum (Cappel-Organon Teknika, Belgium).

Preparation of RNA and Northern blot/RT-PCR analyses for PAFR in primary cell culture. Total cellular RNA was isolated from each culture by the guanidium thiocyanate/CsCl method (MacDonald et al., 1987). The RNA samples $(10 \mu \mathrm{g}$ each) were electrophoresed in $1.2 \%$ agarose gel containing $7 \%$ formaldehyde and were alkaline-transferred onto a Hybond- ${ }^{+}$membrane (Amersham). The blot membrane was incubated at $65^{\circ} \mathrm{C}$ in $10 \mathrm{ml}$ rapid hybridization buffer (Amersham) for $30 \mathrm{~min}$. A $\left[{ }^{32} \mathrm{P}\right] \mathrm{dCTP}-\mathrm{labeled}$ probe was synthesized from the $P v u \mathrm{I}-A v a \mathrm{I}$ fragment $(0.9 \mathrm{~kb})$ of rat PAF receptor cDNA with a random-primed DNA labeling kit (Ready-Prime, Amersham) and added to the hybridization buffer. After incubation on a shaker at $65^{\circ} \mathrm{C}$ for $2 \mathrm{hr}$, the membrane was washed in $50 \mathrm{ml}$ of $2 \times$ SSC containing $0.1 \%$ SDS at room temperature for $30 \mathrm{~min}$ and in $1 \times \mathrm{SSC}$ at $65^{\circ} \mathrm{C}$ for $30 \mathrm{~min}$. The signals were detected by autoradiography on $\mathrm{x}$-ray film. PAFR mRNA expression was evaluated further by reverse transcription-PCR (RT-PCR). The first-strand cDNA was synthesized from $1 \mu \mathrm{g}$ of total RNA from each cell culture. Aliquots (1/50) of the cDNA samples were amplified with PCR using rat PAFRspecific primers: CCGCTGTGGATTGTCTATTA (upstream, $5^{\prime}-3^{\prime}$ ) and AGGAGGTGATGAAGATGTGG (downstream, $5^{\prime}-3^{\prime}$ ) for 25,30 , or 35 cycles with a thermal cycle of $58-72-94^{\circ} \mathrm{C}$ (each for $1 \mathrm{~min}$ ). The PCR products were electrophoresed in agarose gel and visualized by ethidiumbromide staining.

Fluorometric imaging of $\left.\mathrm{Ca}^{2+}\right]_{2}$ in primary cultures of rat microglia and hippocampal cells. Because PAFR mRNA expression was detected in the brain and primary cell culture systems, the functional presence of the receptor was then determined in cultured cells. Fluorometric measurement of intracellular $\mathrm{Ca}^{2+}$ concentration $\left(\left[\mathrm{Ca}^{2+}\right]_{1}\right)$ was carried out using primary cell cultures of (1) microglia isolated from culture of neonatal rat cerebrum and (2) hippocampal cells from E16 rat embryos. PAFR protein itself could not be detected immunohistochemically because no anti-PAFR antibodies were available for this purpose.

(1) Microglia were prepared as described above and maintained on PLL-coated coverslips for 12-24 hr. The cell culture was loaded with $5 \mu \mathrm{M}$ Fura 2-AM (Dojin Chemicals, Kumamoto, Japan) in glutamate-free DMEM (Nissui, Tokyo, Japan) containing fatty acid-free $0.1 \%$ BSA (Sigma) at $37^{\circ} \mathrm{C}$ for $1 \mathrm{hr}$. Fluorometric imaging was carried out with an inverted microscope (TMD30), Nikon, Tokyo, Japan) equipped with fluorescence lenses (Fluor-10 and -40, Nikon) and an ICCD camera/ image analysis systcm (ARGUS-50; I Iamamatsu Photonics, I Iamamatsu, Japan) at $22-25^{\circ} \mathrm{C}$. Eight frames (frame $/ 0.03 \mathrm{sec}$ ) were integrated, and ratio images $(340 / 380 \mathrm{~nm})$ were acquired every $10 \mathrm{sec}$. PAF $(10 \mathrm{nM})$ was bath-applied in the HEPES-Tyrode buffer $(140 \mathrm{~mm} \mathrm{NaCl}, 2.7 \mathrm{~mm} \mathrm{KCl}$, $1.8 \mathrm{mM} \mathrm{CaCl}_{2}, 12 \mathrm{mM} \mathrm{NaHCO}_{3}, 5.6 \mathrm{mM}$ D-glucose, $0.49 \mathrm{~mm} \mathrm{MgCl}_{2}, 0.37$ mM NaH $\mathrm{PO}_{4}, 25 \mathrm{~mm}$ HEPES, pH 7.4) containing 0.1\% BSA.

(2) Primary culture of hippocampal tissues was prepared from rat embryos (E16) as described previously (Banker and Cowan, 1977), with modifications. Briefly, hippocampal tissues were removed and treated with $1 \mathrm{mg} / \mathrm{ml}$ trypsin (Gibco, Gaithersburg, MD) and $0.5 \mathrm{mg} / \mathrm{ml}$ DNase I (Boehringer Mannheim, Germany) in $120 \mathrm{~mm} \mathrm{NaCl}, 5 \mathrm{~mm} \mathrm{KCl}, 25 \mathrm{~mm}$ D-glucosc, $20 \mathrm{~mm}$ PIPES, $\mathrm{pH} 7.0$, for $5 \mathrm{~min}$ at $37^{\circ} \mathrm{C}$. The tissue suspension was centrifuged at $150 \times g$ for $20 \mathrm{sec}$, and the cell pellet was resuspended in $0.3 \mathrm{mg} / \mathrm{ml}$ trypsin inhibitor (Gibco) and $40 \mu \mathrm{g} / \mathrm{ml}$ DNase I in the above buffer. After gentle trituration with a Pasteur pipette, the cells were centrifuged at $150 \times g$ for $3 \mathrm{~min}$. The cell pellet was resuspended in glutamate-free DMEM $/ 10 \%$ horse serum supplemented with $0.1 \mathrm{mg} / \mathrm{ml}$ transferrin (Sigma), $16 \mu \mathrm{g} / \mathrm{ml}$ putrescine (Sigma), $5 \mu \mathrm{g} / \mathrm{ml}$ insulin (Wako Chemicals, Osaka, Japan), $20 \mathrm{~nm}$ progesterone (Sigma), and 30 $\mathrm{nm}$ $\mathrm{Na}_{2} \mathrm{SeO}_{3}$ (Sigma) (Bottenstein, 1985) and plated on polyethylene iminecoated coverslips with four-well silicon chambers (Flexiperm disk, Heraeus Biotechnology, Hanau, Germany) at $1.0 \times 10^{\circ} \mathrm{cclls} / \mathrm{well}$. The culture was maintained for $2 \mathrm{~d}$ in this medium and subsequently for $10-13$ $\mathrm{d}$ in the medium containing $0.1 \%$ fatty acid-free BSA (Pentex, Miles, Kankakee, Illinois) in place of horse serum. The medium was changed every $3 \mathrm{~d}$. Fluorometric $\mathrm{Ca}^{2+}$ imaging was carried out as described above. Before PAF application, the cells were pretreated with $0.5 \mu \mathrm{M}$ tetrodotoxin (Wako Chemicals) in the HEPES-Tyrode buffer containing $0.1 \%$ BSA. After $\left[\mathrm{Ca}^{2+}\right]_{1}$ returned to the baseline level, $\mathrm{Ca}^{2+}$ imaging was repeated in some of the samples with application of $50 \mu \mathrm{M}$ NMDA (Wako Chemicals) in the HEPES-Tyrode buffer/0.1\% BSA to identify neuronal cells.

Immunocytochemical examination of PAF-responsive hippocampal cells. Immediately after the fluorometric imaging, the hippocampal cultures on the coverslips were washed briefly three times with PBS, fixed in $2 \%$ paraformaldehyde/PBS at room temperature for $5 \mathrm{~min}$, washed three times with PBS, fixed in $100 \%$ methanol at $-25^{\circ} \mathrm{C}$ for $30 \mathrm{sec}$, and rinsed with PBS. Subsequently, the samples were incubated in $10 \%$ horse serum/PBS containing $0.1 \mathrm{mM}$ each of $\mathrm{CaCl}_{2}, \mathrm{MgCl}_{2}$, and $\mathrm{MnCl}_{2}$ at room temperature for $10 \mathrm{~min}$ and then in the same solution containing $10 \mu \mathrm{g} / \mathrm{m}$ FITC-labeled isolectin $\mathbf{B}_{4}$ and monoclonal anti-GFAP (1:200, Sigma) or anti-MAP2 antibody (1:500, Sigma) for $45 \mathrm{~min}$ at room temperature. After three brief washes with PBS, the samples were incubated with tetramethylrhodamine isothiocyanate (TRITC)-labeled anti-mouse IgG 

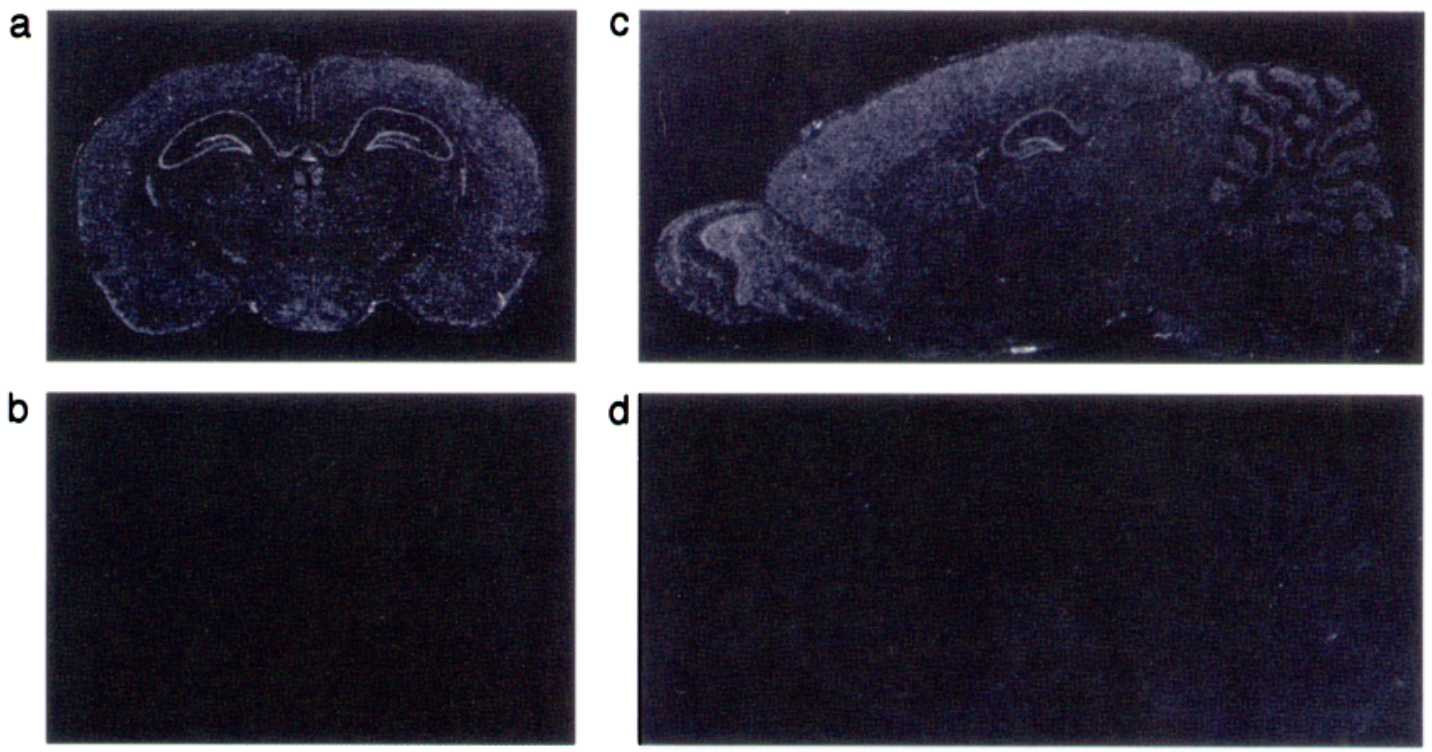

Figure 1. Film-autoradiographic images showing in situ hybridization of PAF receptor mRNA in coronal $(a, b)$ and parasagittal $(c, d)$ sections of adult rat brain. Fresh-frozen rat brain sections $(10 \mu \mathrm{m})$ were hybridized with a ${ }^{35} \mathrm{~S}$-labeled antisense cRNA probe synthesized from a $P v u \mathrm{I}-A v a \mathrm{I}$ fragment $(0.9$ $\mathrm{kb})$ of rat PAF receptor cDNA in the absence $(a, c)$ or presence $(b, d)$ of 100 -fold excess unlabeled cRNA. The hybridized sections were autoradiographed to $\mathrm{x}$-ray film for $8 \mathrm{~d}$. For details, see Materials and Methods.

antibody (1:50; Serotec) in $10 \%$ horse serum/PBS for $30 \mathrm{~min}$ at room temperature. After three brief washes with PBS, the samples were then mounted in $50 \%$ glycerol containing $0.5 \%$ 1,4-diazabicyclo-[2.2.2.] octane (DABCO, Sigma). The stained samples were observed using the fluorescence microscope/ARGUS system described above. FITC and TRITC were visualized under 470 and $540 \mathrm{~nm}$ emission light, respectively, and with appropriate absorption filters. Isolectin $\mathrm{B}_{4}$ and OX-42 (used in immunostaining the sections) both bind to ameboid, ramified, and reactive microglia and thus are suitable markers for detection of a wide variety of microglia (Thomas, 1992; Nakajima and Kohsaka, 1993).

Northern blot analysis for $\mathrm{CPLA} \mathrm{A}_{2}$ in primary cell culture. One of the important outputs of PAFR activation is release of arachidonic acid (Honda et al., 1994). Its release depends mainly on activation of cytosolic phospholipase $\mathrm{A}_{2}$ (cPLA ${ }_{2}$ ) (Clark et al., 1991); however, it has not been clear which cells in the brain express $\mathrm{CPLA}_{2}$. One report showed that astrocytes alone are stained with an anti-cPLA, antibody (Stephenson et al., 1994), but another showed cPLA ${ }_{2}$ mRNA expression in neurons (Owada et al., 1994). Because PAF stimulates arachidonic acid release in astrocytes (Petroni et al., 1994) and a $m y c$-immortalized microglial cell line (Rhigi et al., 1995), the presence of cPLA ${ }_{2}$ was sought in primary cell culture systems. After sufficient time for decay of radioactivity, the membrane used in the analysis of PAFR mRNA expression was rehybridized with a probe synthesized from the coding region $(\sim 2.2 \mathrm{~kb})$ of the mouse cPLA ${ }_{2}$ cDNA (kindly provided by Dr. I. Kudo, Showa University, Tokyo). The subsequent procedures were carried out as described above.

Immunoblot analysis for cPLA $A_{2}$ in microglia. Microglial cells were isolated as described above $\left(\sim 2-4 \times 10^{6}\right.$ cells $/ 75 \mathrm{~cm}^{2}$ flask $)$. The medium was aspirated, and the cells were washed with ice-cold PBS. The flasks were cooled in liquid nitrogen and stored at $-80^{\circ} \mathrm{C}$ until use. The frozen cells were thawed and lysed by the addition of $200 \mu \mathrm{l} /$ flask lysis buffer containing protease inhibitors. The cell lysate was centrifuged at $15,000 \times$ $\mathrm{g}$ for $10 \mathrm{~min}$, and the resulting supernatant was treated with $5 \times$ Laemmli buffer, boiled for $5 \mathrm{~min}$, and subjected to $7.5 \%$ SDS-PAGE $(20 \mathrm{~mA} / \mathrm{gel}$, $20 \mu \mathrm{g}$ protein/lane). After electrophoresis for $6 \mathrm{hr}$, the samples were transferred to a nitrocellulose membrane (Hybond-ECL, Amersham) at $5 \mathrm{~mA} / \mathrm{cm}^{2}$ for $30 \mathrm{~min}$. The blot membrane was blocked with $0.1 \%$ Tween 20 containing $10 \%$ horse serum, washed with $0.1 \%$ Tween 20 , incubated with 1:5000 rabbit anti-human cPLA $_{2}$ (kindly provided by Dr. J. D. Clark, Genetics Institute, Cambridge, MA) for $1 \mathrm{hr}$ and then with peroxidaseconjugated goat anti-rabbit IgG antisera (1:5000; Cappel, West Chester, PA) in $0.1 \%$ Tween 20 containing $10 \%$ horse serum for $30 \mathrm{~min}$. The signal was visualized by chemiluminescence (ECL Western blotting reagents, Amersham).

Arachidonic acid release from PAF-stimulated microglia. Because microglia showed predominant expression of both PAFR and $\mathrm{CPLA}_{2}$, the release of arachidonic acid in PAF-stimulated microglia was characterized. Arachidonic acid release was measured in microglial culture prelabeled with $\left[{ }^{3} \mathrm{H}\right]$ arachidonic acid essentially as described (Lin et al., 1992). Microglial cells $\left(\sim 2 \times 10^{6}\right.$ cells $/ 75 \mathrm{~cm}^{2}$ flask) were incubated with 1 $\mu \mathrm{Ci} / \mathrm{ml}\left[{ }^{3} \mathrm{H}\right]$ arachidonic acid (DuPont NEN) in DMEM/0.1\% BSA for 18 $\mathrm{hr}$ at $37^{\circ} \mathrm{C}$. After two washes with DMEM $/ 0.1 \%$ BSA, the cells were incubated with $0,0.1,1,10,100$, or $1000 \mathrm{~nm}$ PAF in $5 \mathrm{ml} \mathrm{DMEM} / 0.1 \%$ $\mathrm{BSA}$ at $37^{\circ} \mathrm{C}$ for $10 \mathrm{~min}$. The conditioned medium was collected, and the cells were lysed with $1 \%$ Triton X-100. The radioactivity of the medium (A) and the cell lysate (B) was determined in a liquid scintillation counter (Top Count, Packard, Meridian, CT), and $\mathrm{A} /(\mathrm{A}+\mathrm{B})$ was calculated as a release ratio. Because arachidonic acid release by $\mathrm{CPLA}_{2}$ is reported to depend on $\left[\mathrm{Ca}^{2+}\right]_{\mathrm{i}}$ (Clark et al., 1991; Kramer et al., 1991), $\left[\mathrm{Ca}^{2+}\right]_{\mathrm{i}}$ dependence of PAF-stimulated release of arachidonic acid was evaluated in cultured microglia. The microglial cells loaded with $\left[{ }^{3} \mathrm{H}\right]$ arachidonic acid were preincubated in DMEM $/ 0.1 \%$ BSA $/ 1 \%$ dimethylsulfoxide (DMSO) with or without a $\left[\mathrm{Ca}^{2+}\right]_{i}$ chelator, O-O'-bis(2-aminophenyl) ethylene glycol- $N, N, N^{\prime} N^{\prime}$-tetra-acetic acid, tetra-acetoxymethyl ester (BAPTA-AM, Dojin Chemicals), $20 \mu \mathrm{M}$, at $37^{\circ} \mathrm{C}$ for $2 \mathrm{hr}$ and then incubated with $10 \mathrm{nM}$ PAF in $5 \mathrm{ml}$ DMEM/ $/ .1 \%$ BSA for $0,5,10$, or 20 $\mathrm{min}$. The radioactivity of the medium and the cell lysate was determined in the liquid scintillation counter. Next, the $\mathrm{CPLA}_{2}$ products released from PAF-stimulated microglia were analyzed, because arachidonic acid derivatives also constitute bioactive mediators in the CNS (Shimizu and Wolfe, 1990). Isolated microglia $\left(\sim 10^{7}\right.$ cells $)$ were loaded with $\left[{ }^{3} \mathrm{H}\right]$ arachidonic acid and incubated for $10 \mathrm{~min}$ at $37^{\circ} \mathrm{C}$ in the presence or absence of $10 \mathrm{~nm}$ PAF. Lipids were extracted from the conditioned medium and subsequently analyzed with a high-performance liquid chromatography (HPLC)/radio detector system (System Gold, Beckman, Fullerton, CA).

\section{RESULTS}

\section{Ubiquitous expression of PAFR in rat brain}

The in situ hybridization signals were ubiquitous but relatively intense in the cerebral cortex, olfactory bulb, pyramidal cell layer of the hippocampus, medial thalamus, hypothalamus, and granular cell layer of the cerebellum (Fig. 1). In the hippocampus, intense signals were scattered randomly, and moderate signals were found in the pyramidal cell layer and dentate gyrus (Fig. $2 a$ ). In the cerebral cortex, intense signals were scattered randomly in all of the layers, and moderate signals were found in layers II-VI, with relative concentration to layers III, IV, and VI (Fig. 2b). In 

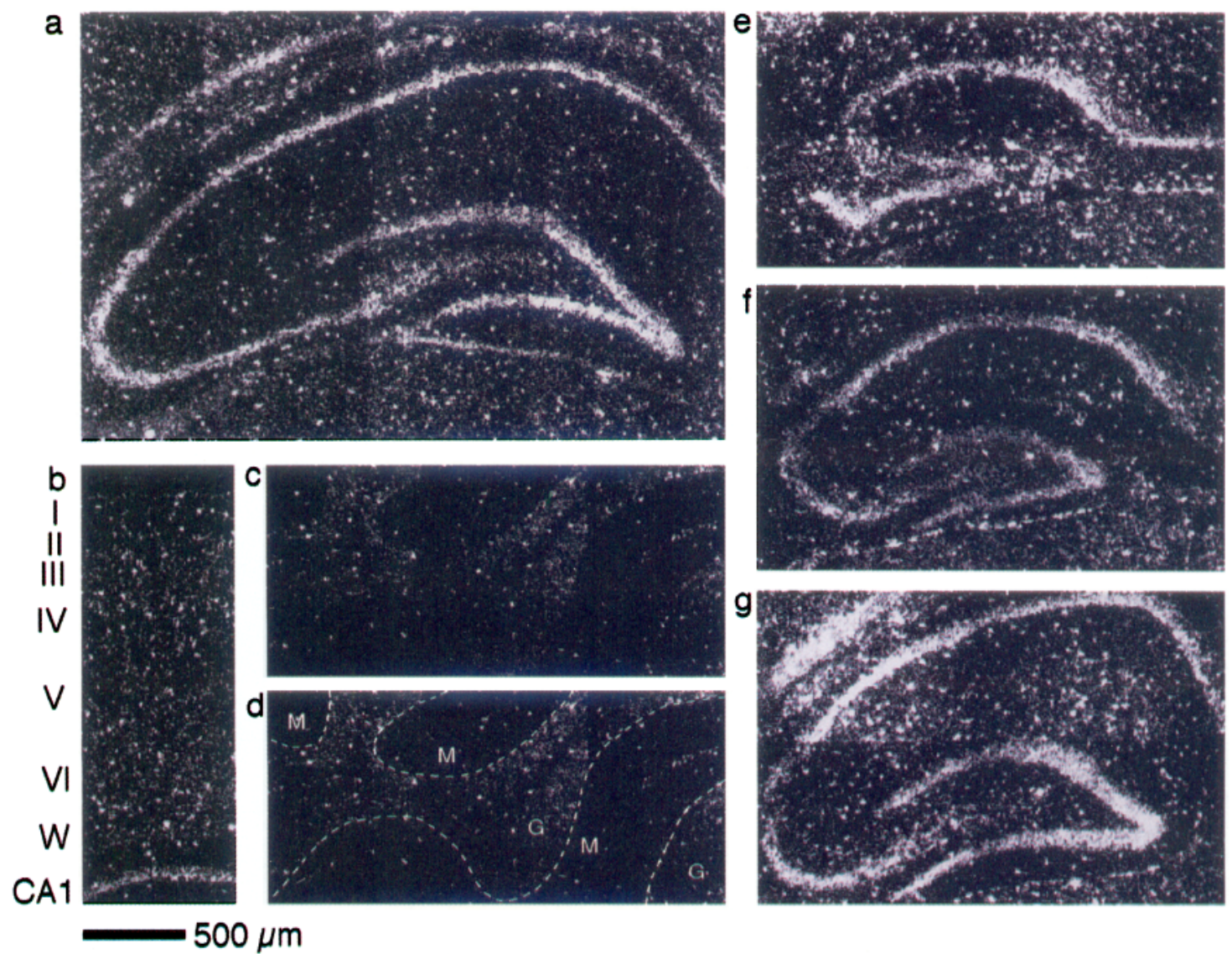

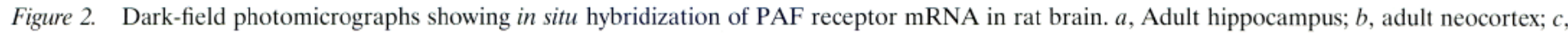

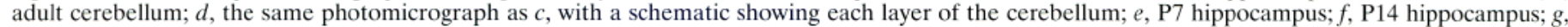

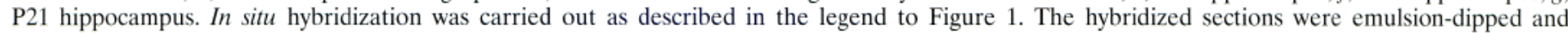

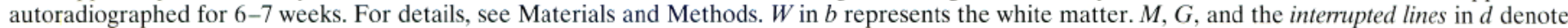
the molecular, granular, and Purkinje layers, respectively.

the cerebellum, intense signals were scattered randomly as in the hippocampus, and slight to moderate signals were found in the granular cell and Purkinje cell layers (Fig. $2 c, d$ ). The scattered distribution of the intense signals was evident throughout the whole brain in both gray and white matter. The signals were not highly concentrated in any specific brain areas or nerve nuclei. The intensity of the signals was constant in film autoradiographs among E18, P0, P7, P14, and P21 brains (data not shown). The distribution pattern of the signals was similar to that of the adult from $\mathrm{P} 7$ in the hippocampus (Fig. $2 e-g$ ) and also in the other brain regions (data not shown).

\section{Predominant expression of PAFR in microglia in rat brain}

The PAFR-expressing cells could be classified into at least two groups (Fig. $3 a, b$ ). One type of cells was densely labeled and had small nuclei that stained darkly with cresyl violet. Most of these nuclei were of angular or irregular shapes. The cells of this group were scattered ubiquitously and randomly in both gray and white matter. These findings suggest that microglia comprise this group (del Rio-Hortega, 1932; Vaughan, 1984). The other group of cells was labeled moderately and had larger nuclei that stained lightly. These cells were found most frequently in layers II-VI of the cerebral cortex but not in layer I. They were also found in the pyramidal cell layers of the hippocampus (Fig. $3 a$, indicated by an arrow). These findings suggest that the second group includes neurons. No intense signals were found in cells with round and moderately stained nuclei, which characterize astrocytes (del RioHortega, 1932; Vaughan, 1984). Table 1 summarizes the intensity of the hybridization signals as evaluated by the number of grains per cell. The number of grains on microglia were outstanding from P7 to adult, exceeding more than twice those on neurons.

Immunohistochemistry followed by in situ hybridization revealed that almost all of the densely labeled cells are OX-42-positive but anti-GFAP-negative in the adult rat brain (Fig. $3 c-f$ ). This indicated that microglia express PAFR mRNA the most intensely; however, because all of the OX-42-positive cells were not labeled, microglia apparently are heterogeneous in terms of PAFR mRNA expression. On the other hand, all of the anti-GFAP-positive cells were labeled only slightly, if at all. Weak or moderate signals were found in OX-42- and anti-GFAP-negative cells with large nuclei, which apparently were neurons (data not shown). The intensely labeled cells in the pup brain were also probably microglia. We could not confirm it successfully with immunohistochemistry, however, because immunostaining pup brain sections required longer incubation with the antibody, which diminished the signals of the following hybridization, possibly by degrading RNA.

\section{Predominant expression of PAFR in cultured microglia}

Northern blot analysis revealed that PAFR mRNA expression is predominant in microglia and hardly detectable in neurons, astrocytes, and fibroblasts (Fig. 4). In the RT-PCR analysis, the 
a

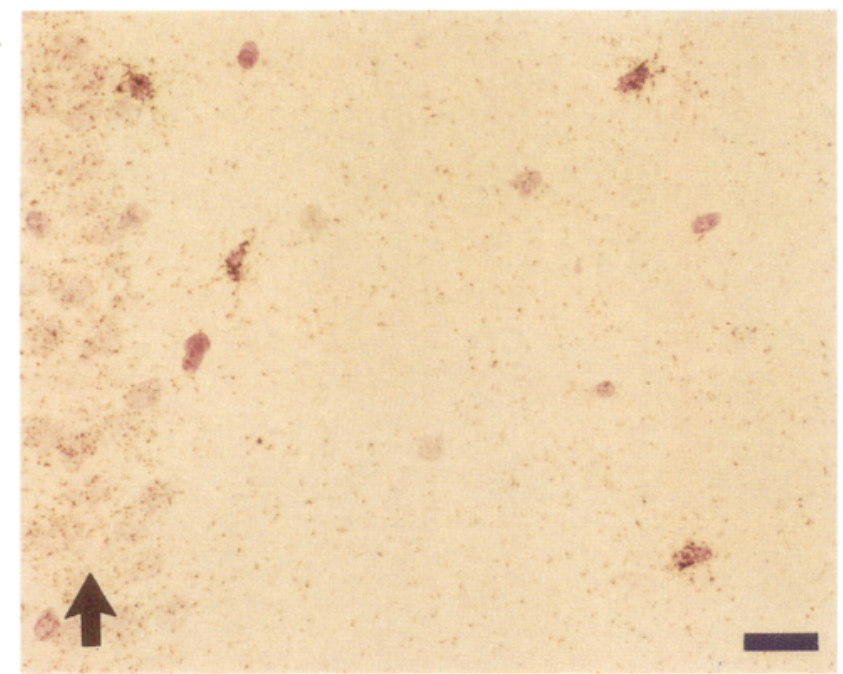

C

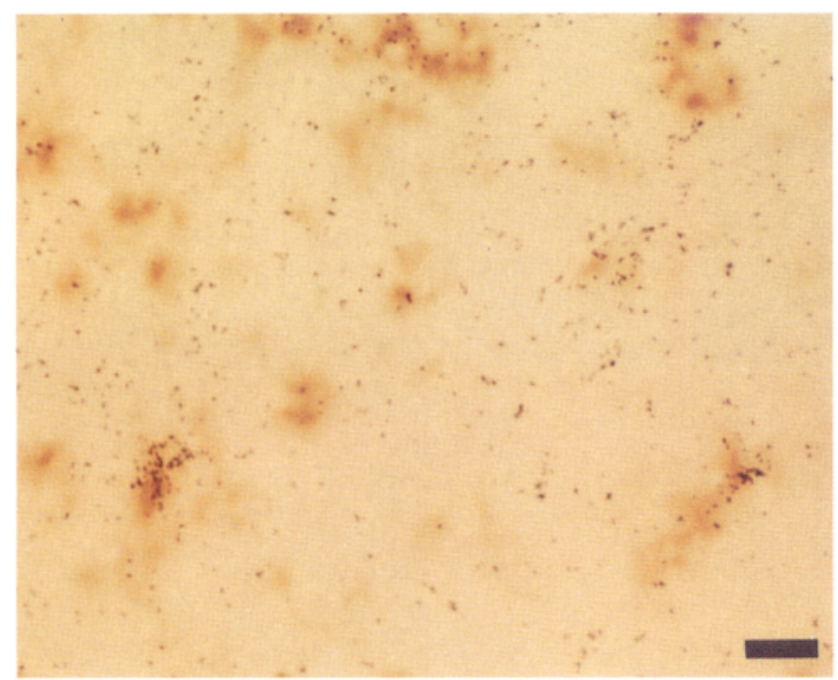

e

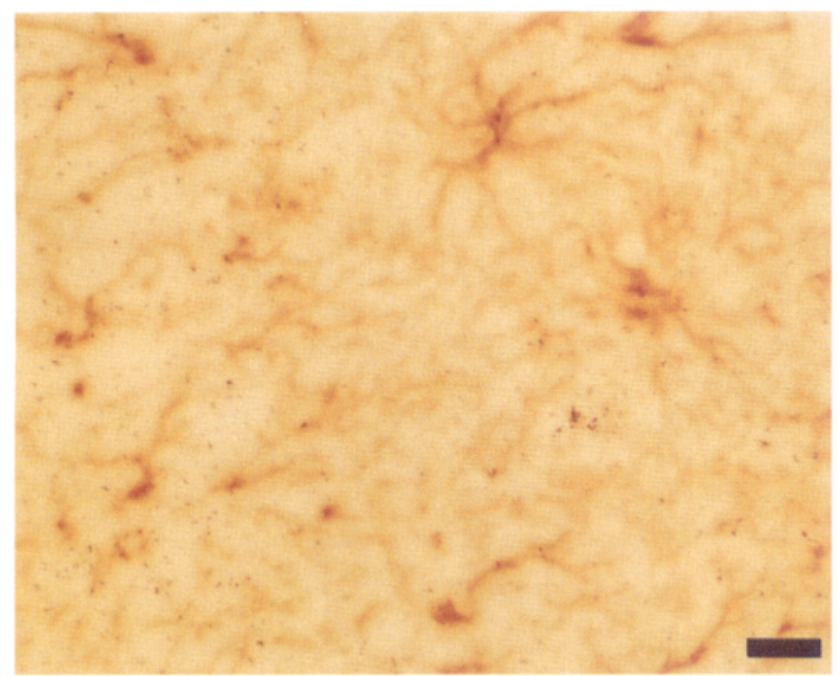

b

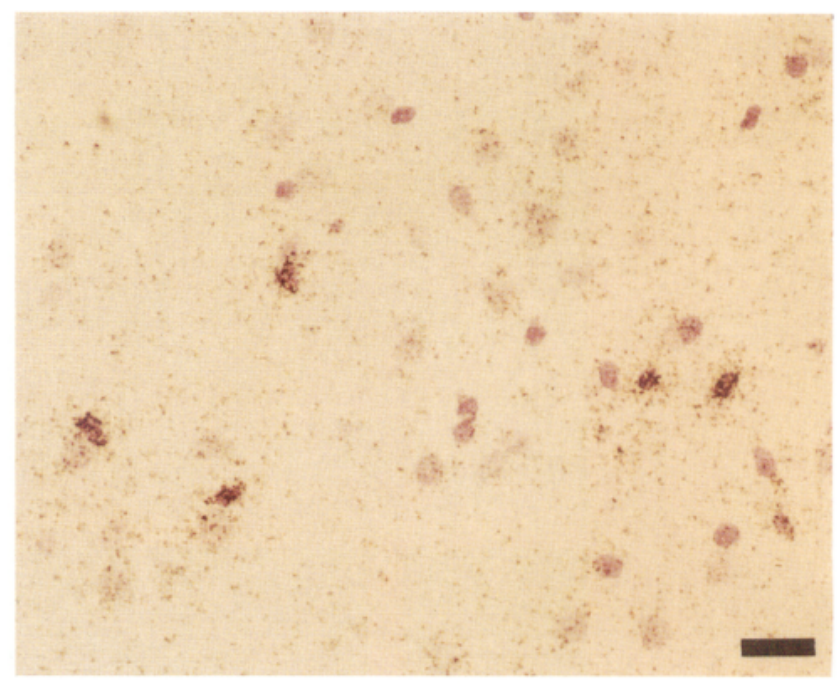

d

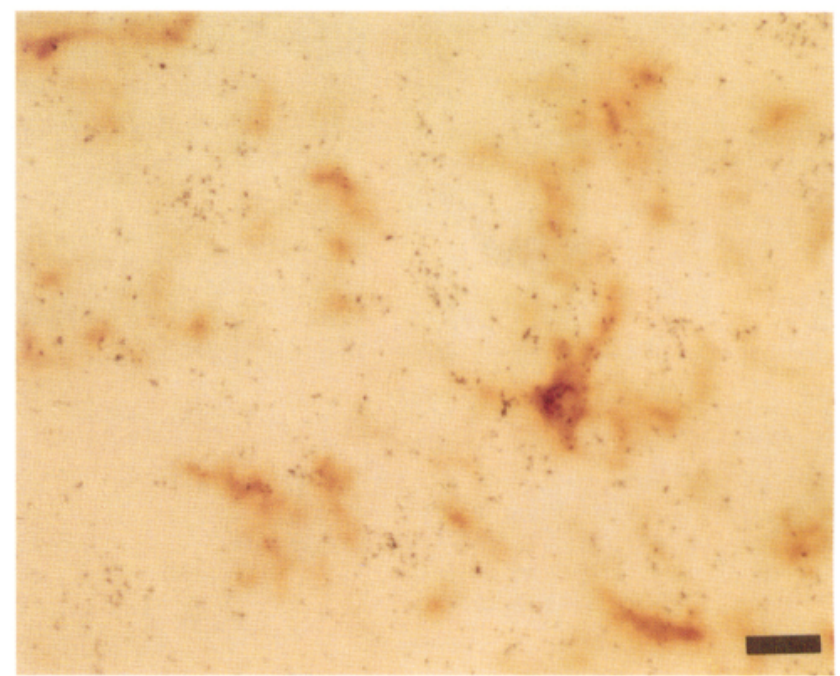

f

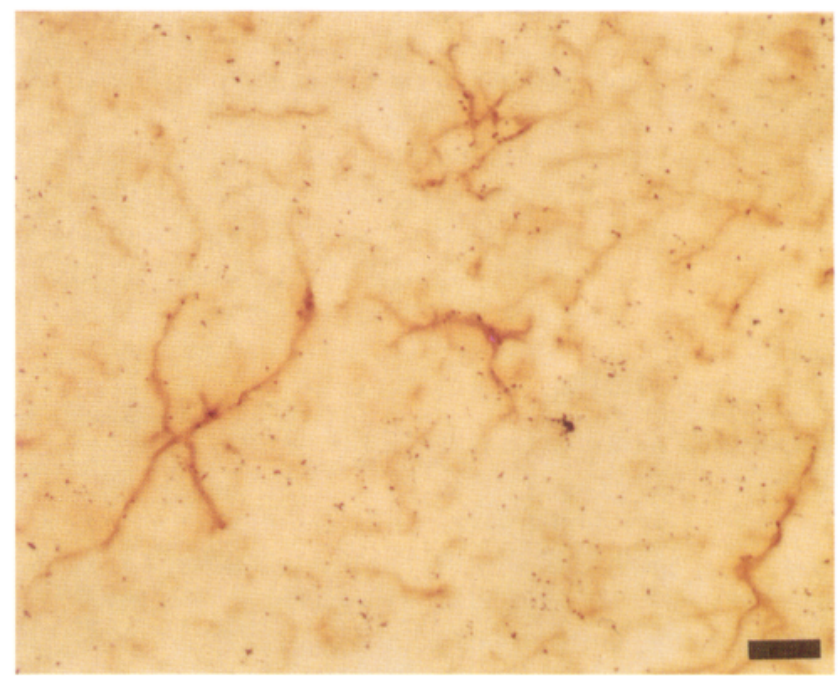

Figure 3. Bright-field photomicrographs showing in situ hybridization of PAF receptor mRNA in adult rat hippocampal $(a, c, e)$ and cortical $(b, d, f)$ sections stained with cresyl violet $(a, b), \mathrm{OX}-42(c, d)$, or anti-GFAP antibody $(e, f)$. In situ hybridization and immunostaining were carried out as described in Materials and Methods. Intense labeling is found in cells with small and darkly stained nuclei that have angular or irregular shapes $(a, b)$, and in OX-42-positive cells $(c, d)$ but not in anti-GFAP-positive cells $(e, f)$. The arrow in $a$ shows the pyramidal cell layer. Scale bars: $a, b, 20 \mu$ m; $c-f, 10 \mu$ m. 
Table 1. Expression levels of PAF receptor mRNA in the rat brain

\begin{tabular}{lllll} 
& \multicolumn{4}{l}{ Number of grains per cell } \\
\cline { 2 - 5 } Tissue & P7 & P14 & P21 & Adult \\
\hline Microglia & ++++ & ++++ & ++++ & ++++ \\
Neuron & & & & \\
Neocortex & +-++ & ++ & ++ & ++ \\
CA1 (pyramidal cell layer) & ++ & ++ & ++ & ++ \\
Dentate gyrus & + & + & + & + \\
\hline
\end{tabular}

Number of grains per cell:,$+<10 ;++, 10-19 ;+++, 20-39 ;++++, 40-80$. P7, 7-d-old; P14, 14-d-old; P21, 21-d-old. Microglia and neurons were identified by the Nissl-staining characteristics as described in Materials and Methods.

specific PCR product $(\sim 0.38 \mathrm{~kb})$ apparently was detected in the RNA from microglia ( $\geq 25$ cycles), astrocytes ( $\geq 30$ cycles), and neurons ( 35 cycles) but not in fibroblasts ( 35 cycles) (Fig. 5). The specificity of PCR amplification was confirmed by complete digestion of the products with $E c o R V$, whose restriction site was mapped in the middle of the amplified region of the PAF receptor cDNA (data not shown).

\section{PAF-elicited $\left[\mathrm{Ca}^{2+}\right]_{\mathrm{i}}$ response in cultured cells Isolated microglia}

PAF $(10 \mathrm{~nm})$ elevated $\left[\mathrm{Ca}^{2+}\right]_{\mathrm{i}}$ in almost all $(>95 \%)$ of the isolated microglial cells. Figure $6 a, b$ shows imaging of $\left[\mathrm{Ca}^{2+}\right]_{\mathrm{i}}$ in four PAF-treated microglial cells and their temporal profiles, respectively.

\section{Hippocampal culture}

PAF $(10 \mathrm{~nm})$ elevated $\left[\mathrm{Ca}^{2+}\right]_{\mathrm{i}}$ in a small population of the cultured hippocampal cells. Not more than a few PAF-responsive cells were found in one observation field $(\sim 1 \times 1 \mathrm{~mm})$. This

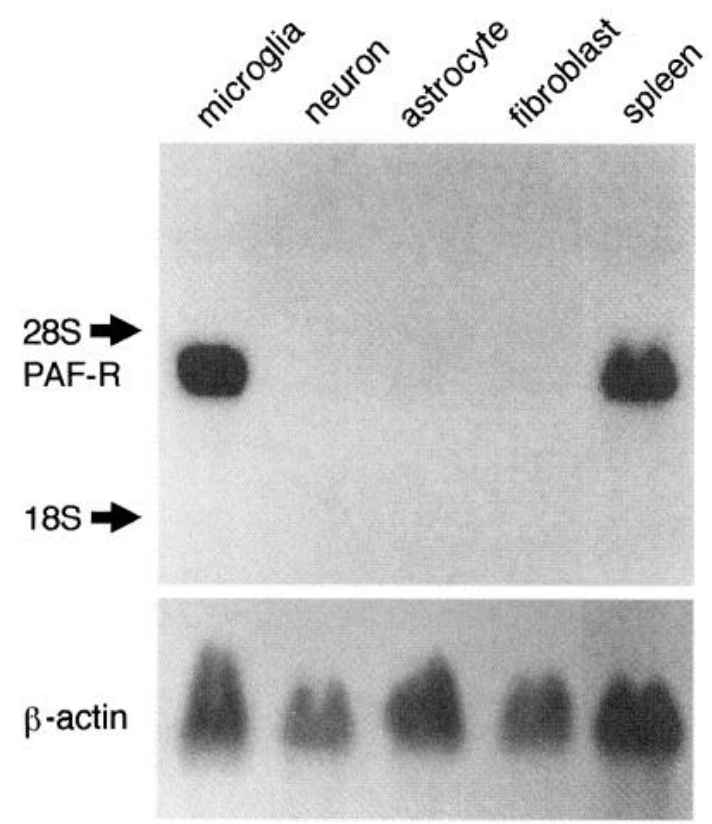

Figure 4. Northern blot analysis of PAF receptor mRNA expression in primary cell culture of microglia, neurons, astrocytes, and fibroblasts prepared from rat brain. Total RNA $(10 \mu \mathrm{g})$ from cultured cells was loaded in each of the left four lanes, and poly $(\mathrm{A})^{+}$RNA $(5 \mu \mathrm{g})$ from adult rat spleen was loaded in the right lane. The blot membrane was hybridized with a $\left[{ }^{32} \mathrm{P}\right] \mathrm{dCTP}$-labeled probe synthesized from the $P v u \mathrm{I}-A v a \mathrm{I}$ fragment $(0.9 \mathrm{~kb})$ of rat PAF receptor cDNA. The bottom shows control hybridization with a $\beta$-actin probe. For details, see Materials and Methods.

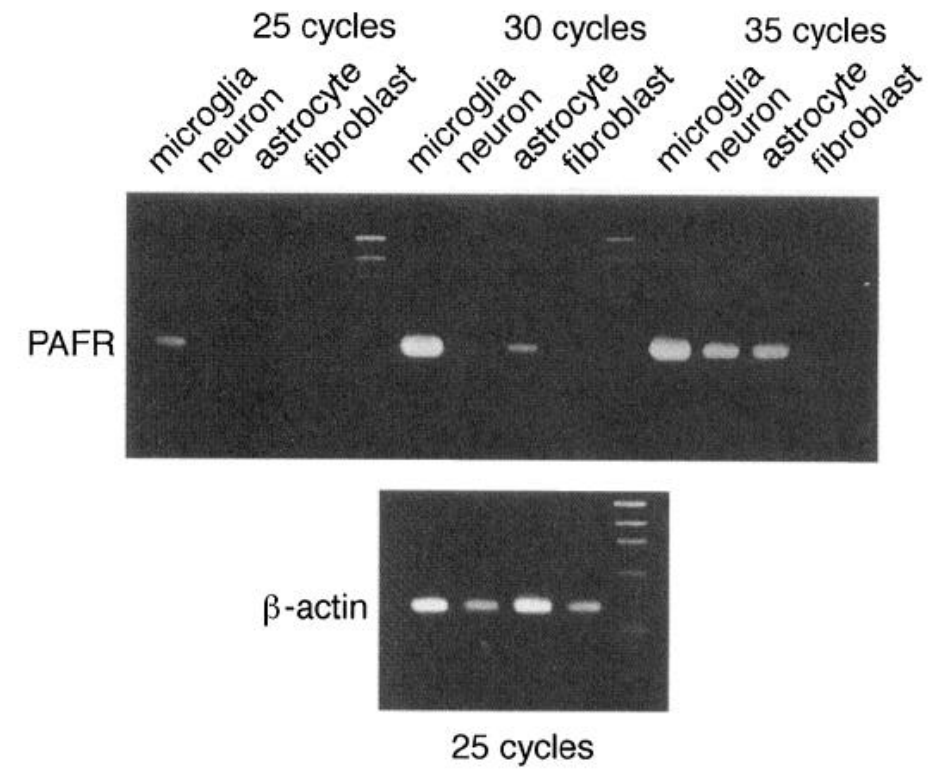

Figure 5. RT-PCR analysis of PAF receptor mRNA in primary cell culture of microglia, neurons, astrocytes, and fibroblasts prepared from rat brain. The first-strand cDNA was synthesized from $1 \mu \mathrm{g}$ of total RNA from each cell culture. Aliquots (1/50) of the cDNA samples were amplified with PCR using rat PAFR-specific primers: CCGCTGTGGATTGTCTATTA (upstream, 5'-3') and AGGAGGTGATGAAGATGTGG (downstream, $5^{\prime}-3^{\prime}$ ) for the indicated number of cycles with a thermal cycle of $58^{\circ} \mathrm{C}, 72^{\circ} \mathrm{C}, 94^{\circ} \mathrm{C}$ (each for $1 \mathrm{~min}$ ). The PCR products were electrophoresed in agarose gel and visualized by ethidium-bromide staining. $\phi$ X174 DNA-HaeIII digest was used as a DNA size marker.

finding was reproducible in $>10$ samples prepared from different embryos on different occasions. Immediately after fluorometry, the culture was stained simultaneously with isolectin $\mathrm{B}_{4}$ for microglia and with anti-MAP2 antibody for neurons or an antiGFAP antibody for astrocytes. More than $90 \%$ of the PAFresponsive cells were stained with isolectin $\mathrm{B}_{4}$ but not with the anti-GFAP antibody, suggesting that they are mostly microglia. On the other hand, not all of the isolectin $\mathrm{B}_{4}$-positive cells responded to PAF, suggesting that the microglia in these conditions are heterogeneous in terms of PAFR expression. This is compatible with the results of immunohistochemistry followed by in situ hybridization. Figure $6 c-e$ shows an example of the fluorometric and immunocytochemical results. Isolectin $\mathrm{B}_{4}$-negative cells only occasionally responded to PAF. These isolectin $\mathrm{B}_{4^{-}}$ negative and PAF-responsive cells partly responded to NMDA and showed MAP2 immunoreactivity (Fig. $6 f-h$ ), suggesting that some neurons express functional PAFR. Also, a small portion of these cells showed GFAP immunoreactivity (data not shown), suggesting that astrocytes also express functional PAFR, albeit to a much smaller degree.

\section{Predominant expression of $\mathrm{CPLA}_{2}$ in cultured microglia}

Northern blot analysis revealed that microglia predominantly ex-

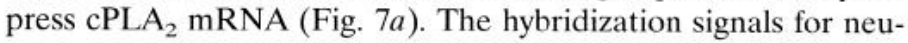
rons, astrocytes, and fibroblasts are scarcely visible in the figure but were detectable in the original autoradiograph. Additionally, the immunoblot analysis demonstrated that $\mathrm{CPLA}_{2}$ protein is present in microglia (Fig. $7 b$ ).

\section{Arachidonic acid release from PAF-stimulated microglia}

The arachidonic acid release from microglia was dose- and timedependent. The optimal PAF concentration was $10 \mathrm{~nm}$ (Fig. 8a), 

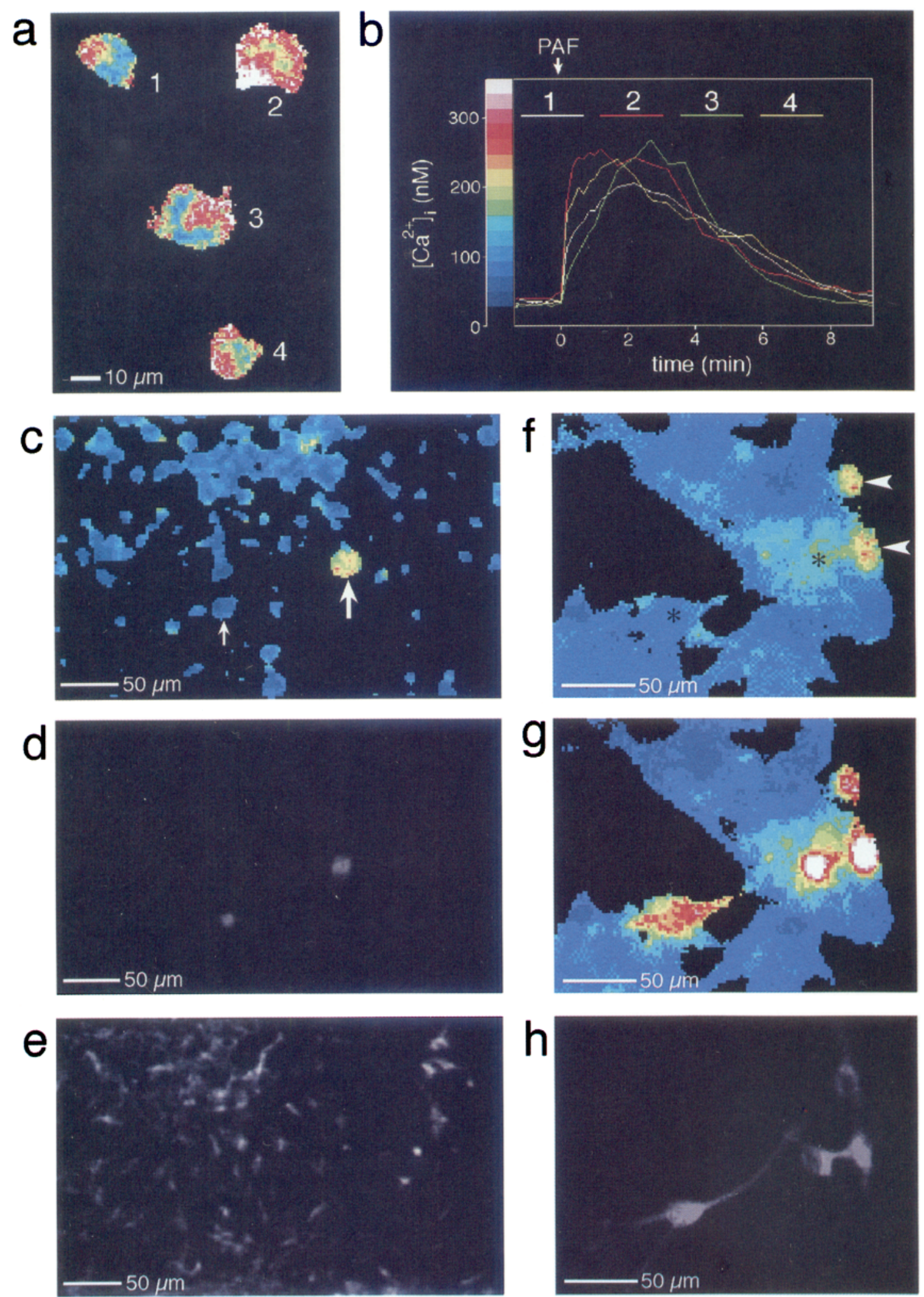

Figure 6. Fluorometric $\left[\mathrm{Ca}^{2+}\right]_{i}$ imaging of PAF-treated microglial and hippocampal cultures. Fluorometric $\mathrm{Ca}^{2+}$ imaging and immunostaining were carried out as described in Materials and Methods. PAF (10 nM) was bath-applied for 1 min. $a,\left[\mathrm{Ca}^{2+}\right]_{\mathrm{i}}$ of four isolated microglial cells 20 sec after PAF application; $b$, time courses of $\left[\mathrm{Ca}^{2+}\right]_{i}$ in the cells in $a ; c,\left[\mathrm{Ca}^{2+}\right]_{\mathrm{i}}$ of hippocampal culture $20 \mathrm{sec}$ after PAF application; $d$, the same culture stained with isolectin $\mathrm{B}_{4} ; e$, the same culture stained with anti-GFAP; $f,\left[\mathrm{Ca}^{2+}\right]_{i}$ of another hippocampal culture $20 \mathrm{sec}$ after PAF application; $g$, $\left[\mathrm{Ca}^{2+}\right]_{i}$ of the same culture $20 \mathrm{sec}$ after NMDA application; $h$, the same culture stained with anti-MAP2. In one hippocampal culture (c-e), one of the two isolection $\mathrm{B}_{4}$-positive cells (large arrow) responded to PAF, whereas the other (small arrow) did not. Note that the former cell is anti-GFAP-negative. In another culture $(f-h)$, two (arrowheads) of the four NMDA-responsive and MAP2-positive cells responded to PAF, whereas the other two (asterisks) did not. These four cells were OX-42-negative (data not shown). The corresponding $\left[\mathrm{Ca}^{2+}\right]_{\mathrm{i}}$ is indicated by the color scale shown in $b$. 


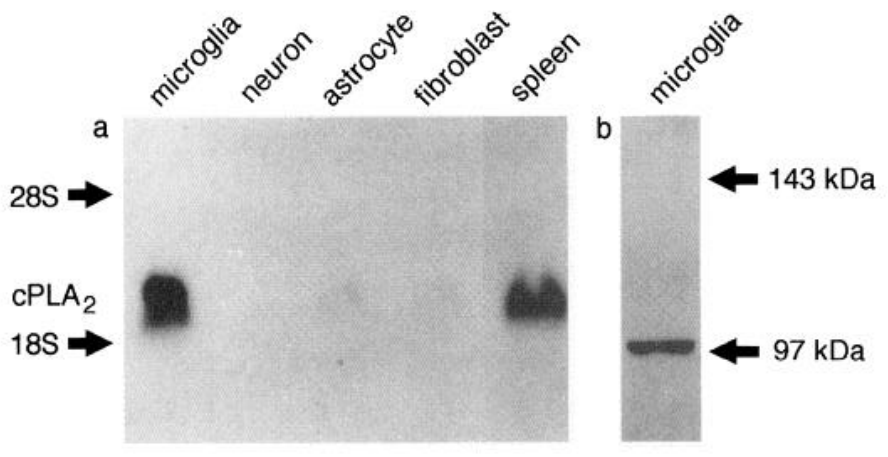

Figure 7. $a$, Northern blot analysis of cytosolic phospholipase $\mathrm{A}_{2}\left(\mathrm{cPLA}_{2}\right)$ mRNA expression in primary cell cultures of microglia, neurons, astrocytes, and fibroblasts prepared from rat brain. The blot membrane used in hybridization with the PAFR probe was rehybridized with a $\mathrm{CPLA}_{2}$ probe. $b$, Immunoblot analysis of $\mathrm{cPLA}_{2}$ in primary cell culture of microglia. For details, see Materials and Methods.

and the net (treated minus untreated) release reached a plateau in 10 min (Fig. 8b). Preincubation with BAPTA-AM decreased the arachidonic acid release by $\sim 50 \%$, indicating that the release is partially dependent on $\left[\mathrm{Ca}^{2+}\right]_{i}$ (Fig. $8 b$ ). Fluorometric $\mathrm{Ca}^{2+}$ imaging confirmed that the BAPTA-AM treatment suppressed 10 nM PAF-elicited rise in $\left[\mathrm{Ca}^{2+}\right]_{i}$ in microglia prepared on a coverslip (data not shown). In the HPLC/radiodetector analysis of the conditioned media of the microglia, all the radioactivity $\left(\sim 2 \times 10^{4}\right.$ cpm for PAF-treated microglia and $\sim 1 \times 10^{4} \mathrm{cpm}$ for untreated microglia) was eluted with the same retention time as standard arachidonic acid. No radioactivity peaks corresponding to prostaglandins or hydroxyeicosatetraenoic acids (HETEs) were detected in the medium of microglia incubated with or without $10 \mathrm{~nm}$ PAF
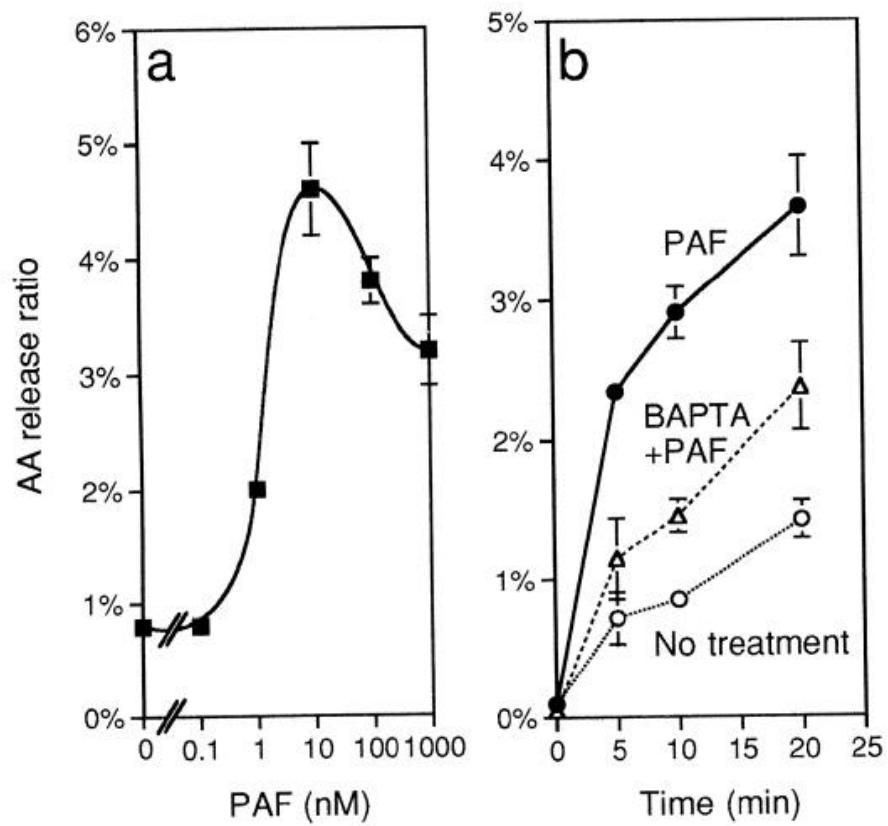

Figure 8. Dose-response relationship $(a)$ and $\mathrm{Ca}^{2+}$-dependent time course $(b)$ of arachidonic acid release from PAF-treated microglia. $a$, Microglial cells prelabeled with $\left[{ }^{3} \mathrm{H}\right]$ arachidonic acid were incubated with $10 \mathrm{nM}$ PAF for $10 \mathrm{~min} . b$, Microglial cells prelabeled with $\left[{ }^{3} \mathrm{H}\right]$ arachidonic acid were preincubated with $20 \mu \mathrm{M}$ BAPTA-AM/1\% DMSO or $1 \%$ DMSO only, and then incubated with or without $10 \mathrm{~nm}$ PAF for the indicated time. For details, see Materials and Methods. The mean and SD are shown $(n=3)$. (data not shown). Because this system detects $100 \mathrm{cpm}$ radioactivity peaks, these results indicate that $>99 \%$ of the released arachidonic acid remained unmetabolized.

\section{DISCUSSION}

\section{Predominant PAFR expression in microglia}

Predominant expression of PAFR mRNA in microglia was demonstrated by in situ hybridization and Northern blot/RT-PCR analyses. PAFR mRNA expression in neurons was more apparent in in situ hybridization than in Northern blot analysis. This discrepancy may be ascribed to differences between the whole animal and primary cell culture systems. The results strongly suggest predominant presence of PAF receptor in microglia, although mRNA levels do not necessarily parallel the protein amount.

Fluorometric $\left[\mathrm{Ca}^{2+}\right]_{\mathrm{i}}$ imaging revealed that PAF-responsive cells in primary hippocampal cultures were mostly microglia. We also confirmed the results of our previous report that a small number of neurons also respond to PAF (Bito et al., 1992). The present results, taken together, show that microglia constitute the major population in the hippocampal cells that functionally express PAFR.

Predominant PAFR expression in microglia is a reasonable finding, because microglia are related to macrophages (Thomas, 1992; Nakajima and Kohsaka, 1993), which have a large number of PAF receptors (Hayashi et al., 1991; Ring et al., 1993) and express PAFR mRNA intensely (Ishii et al., 1996). This finding also seems relevant to the fact that in humans the leukocytes and brain express only PAFR transcript 1 (leukocyte type), one of the two different species of PAFR mRNA (Mutoh et al., 1993, 1996), although splice variants for PAFR have not been studied in rats.

Immunohistochemistry followed by in situ hybridization revealed that PAFR is expressed in some OX-42-positive cells. In primary hippocampal cultures, PAF also elicited calcium response in some isolectin $\mathrm{B}_{4}$-positive cells. The cause of this heterogeneity is presently unclear. One possibility is that microglia are categorized into several subclasses of cells with different levels of PAFR expression. Another is that one microglial cell may change the level of PAFR mRNA expression, depending on certain factors. In fact, transcription of human PAFR transcript 1 in the brain is regulated by activation of protein kinase $\mathrm{C}(\mathrm{PKC})$ through $\mathrm{NF}-\kappa \mathrm{B}$ or by PAF itself (Mutoh et al., 1994). Thus it is likely that various pathophysiological stimuli that activate PKC may induce PAFR mRNA expression in microglia.

\section{PAFR expression in CNS development}

PAFR expression in the rat brain was constant, at least from E18. The characteristic pattern of in situ hybridization signals, i.e., scattered distribution of intensely labeled cells with small and dark-stained nuclei, was observed from P7. The involvement of PAF in CNS development has been suggested, because deficiency of a subunit of a PAF-inactivating enzyme results in Miller-Dieker lissencephaly or agyria (Reiner et al., 1993; Hattori et al., 1994), a disorder attributable to incomplete migration of immature neurons to the cerebral cortex. There is also a hypothesis that microglia contribute to eliminating cells that die through developmentassociated cell death (Thomas, 1992). In light of all of these events, PAF-activated microglia may play a role in developmental events in the CNS such as neuronal selection and migration.

\section{Predominant expression of $\mathrm{CPLA}_{2}$ in microglia}

In our primary cell culture systems, $\mathrm{cPLA}_{2}$ was predominantly expressed in microglia, a finding in contrast to two previous 
reports. One showed that anti-cPLA $\mathrm{C}_{2}$ antibody exclusively stains astrocytes in the rat brain (Stephenson et al., 1994), and the other showed by in situ hybridization that $\mathrm{CPLA}_{2} \mathrm{mRNA}$ is expressed in rat neurons after ischemia (Owada et al., 1994). These discrepancies may be ascribed to the differences between the brain and cell culture and between mRNA and protein. Nevertheless, cPLA $_{2}$ in microglia deserves further attention, and the pathophysiological relevance of its function and transcriptional regulation needs to be evaluated.

\section{Release and metabolism of arachidonic acid in PAF-treated microglia}

PAF-treated microglia efficiently released arachidonic acid, a finding compatible with the predominant PAFR and $\mathrm{CPLA}_{2}$ expression in microglia. The optimal concentration of PAF for arachidonic acid release was $10 \mathrm{nM}$. The same concentration is also optimal for arachidonic acid release in CHO cells stably expressing the guinea pig PAFR gene (Honda et al., 1994). The release of arachidonic acid decreased by $\sim 50 \%$ after treatment with an intracellular $\mathrm{Ca}^{2+}$ chelator, BAPTA-AM. The $\mathrm{Ca}^{2+}$ dependence of PAF-induced arachidonic acid release agrees with the finding that PLA $_{2}$ is activated when translocated to the membrane by a rise in $\left[\mathrm{Ca}^{2+}\right]_{1}$ (Clark et al., 1991). The increase in $\mathrm{PLA}_{2}$ activity in the absence of $\mathrm{Ca}^{2+}$ rises might suggest the presence of $\mathrm{Ca}^{2+}$-independent $\mathrm{PLA}_{2}$ in microglia, although we presently have no direct evidence for its presence. The released arachidonic acid was scarcely metabolized to its derivatives, e.g., HETEs, leukotrienes, and prostaglandins. These findings are in contrast to those obtained in peripheral macrophages and compatible with the recent report that PAF treatment of a mycimmortalized microglial cell line causes arachidonic acid release but no detectable production of 6-keto prostaglandin $F_{1} \alpha$ and leukotriene $\mathrm{B}_{4}$ (Rhigi et al., 1995).

\section{Possible involvement of microglia in PAF effects on CNS}

Accumulated evidence has shown that PAF plays crucial roles in both physiological and pathological conditions in the CNS: PAF modulates synaptic transmission (Clark et al., 1992), induces LTP (Wieraszko et al., 1993; Kato et al., 1994), and contributes to neuronal cell injury (Panetta et al., 1989; Gilboe et al., 1991; Prehn and Krieglstein, 1993). These PAF effects have been assumed as direct actions of PAF on neurons. Our findings, however, suggest that PAF-stimulated microglia also may be responsible at least in part for the known effects of PAF on neurons.

Microglia are known to affect neurons by releasing mediators, including reurotransmitters and neuromodulators, by phagocytosis, and by displacement of synapses (synaptic stripping) (Banati et al., 1993; Nakajima and Kohsaka, 1993). In the case of PAFactivated microglia, one can speculate about the possible involvement of the following neurotransmitter/modulators in altering synaptic transmission. (1) Glutamate: This excitatory amino acid is released from activated microglia and causes neuronal cell death (Piani et al., 1991). Whether it is released from PAFactivated microglia should be clarified in an additional study. (2) Arachidonic acid: This lipid messenger potentiates NMDA receptor currents (Miller et al., 1992), induces LTP (Williams et al., 1989; Kato et al., 1991), and inhibits the high-affinity glutamate uptake system in synaptosomes and astrocytes (Barbour et al., 1989; Volterra et al., 1992). The present study revealed that PAF-stimulated microglia release arachidonic acid without notable conversion to its derivatives. (3) NO: This gaseous mediator induces LTP (Dawson and Snyder, 1994) and is also involved in microglia-mediated nerve cell injury (Boje and Arora, 1992; Chao et al., 1992; Merrill et al., 1993). Whether PAF-activated microglia release NO remains to be clarified in a future study. (4) PAF: Microglia may release PAF itself, because PAF activates the $\mathrm{CPLA}_{2}$ activity in microglia. If this were the case, PAF could serve as an autacoid messenger, thus forming a positive feedback loop. Simultaneous increase in both arachidonic acid and PAF may have synergistic effects on synaptic transmission. In addition to these mediators, there is a possibility that PAF-activated microglia release potentially cytotoxic substances such as free oxygen radicals, proteolytic enzymes, inflammatory cytokines, and unidentitied neurotoxins. Indeed, microglia/macrophages, when activated by zymosan (Giulian et al., 1993b), neuronal injury (Giulian et al., 1993a), IIIV infection (Giulian et al., 1990), or gp120 protein (Lipton et al., 1991; Lipton, 1992) release neurotoxic factor(s) that act presumahly through activation of NMDA receptors. We are now evaluating neurotoxicity of PAF-stimulated microglia and determining whether such neurotoxins are involved. On the other hand, phagocytosis and neuronal stripping by PAFactivated microglia have not been reported. Nevertheless, PAF injection into the mouse hippocampus induces morphological activation of microglia (Andersson et al., 1992). Because PAF (Panetta et al., 1989; Gilboe et al., 1991; Prehn and Krieglstein, 1993) and phagocytosis by microglia (Lees, 1993) both contribute to delayed neuronal cell death after ischemia, it is possible that microglia act as phagocytes to neurons in response to PAF produced after ischemia.

The present findings suggest the possibility that the PAFrelated events in the CNS arise not only from neuron-neuron interactions but also from a complex web of interactions between neurons and glia, in particular, microglia. To understand the roles of PAF in this web, one should first answer the following questions. (1) What are the outputs of PAFR activation in microglia and other cells? (2) Which cells, under which conditions, produce PAF? (3) How does PAF interact with other mediators, including NO and arachidonic acid? Monocytes-astroglia interactions reportedly produce PAF, arachidonic metabolites, and cytokines in HIV infection (Genis et al., 1992; Gelbard et al., 1994). Furthermore, one should also answer the question about whether there are any PAF receptors other than the PAFR that was cloned in our laboratory, because the presence of distinct PAF binding sites in intracellular membranes has been reported (Bazan et al., 1993; Bazan, 1994). Some of these critical questions will be answered shortly when PAFR-deficient mice are established and their phenotypes are analyzed.

\section{REFERENCES}

Andersson PB, Perry VH, Gordon S (1992) Intracerebral injection of proinflammatory cytokines or leukocyte chemotaxins induces minimal myelomonocytic cell recruitment to the parenchyma of the central nervous system. J Exp Med 176:255-259.

Banati R, Gehrmann J, Schubert P, Kreutzberg G (1993) Cytotoxicity of microglia. Glia 7:111-118.

Banker G, Cowan W (1977) Rat hippocampal neurons in dispersed cell culture. Brain Res 126:397-425.

Barbour B, Szatkowski M, Irigledew N, Attwell D (1989) Arachidonic acid induces a prolonged inhibition of glutamate uptake into glial cells. Nature 342:918-920.

Bazan NG (1994) Platelet-activating factor is a synapse messenger and an intracellular modulator of gene expression. J Lipid Mediat Cell Signal 10:83-86.

Bazan NG, Zorumski CF, Clark GD (1993) The activation of phospholipase $\mathrm{A} 2$ and release of arachidonic acid and other lipid mediators at 
the synapse: the role of platelet-activating factor. $\mathbf{J}$ Lipid Mediators 6:421-427.

Benveniste J, Tence M, Varenne P, Bidault J, Boullet C, Polonsky J (1979) Semi-synthèse et structure purposée du facteur activant les plaquettes (PAF); PAF-acether, un alkyl ether analogue de la lysophosphatidylcholine. C R Acad Sci [D] (Paris) 289:1037-1040.

Bito H, Honda Z, Nakamura M, Shimizu T (1994) Cloning, cxprcssion and tissue distribution of rat platelet-activating-factor-receptor cDNA. Eur J Biochem 221:211-218.

Bito H, Nakamura M, Honda Z, Izumi T, Iwatsubo T, Seyama Y, Ogura A, Kudo Y, Shimizu T (1992) Platelet-activating factor (PAF) receptor in rat brain: PAF mobilizes intracellular $\mathrm{Ca}^{2+}$ in hippocampal neurons. Neuron 9:285-294.

Blank ML, Snyder F, Byers LW, Brooks B, Muirhead EE (1979) Antihypertensive activity of an alkyl ether analog of phosphatidylcholine. Biochem Biophys Res Commun 90:1194-1200.

Boje KM, Arora PK (1992) Microglia-produced nitric oxide and reactive nitrogen oxides mediate neuronal cell death. Brain Res 587:250-256.

Bottenstein J (1985) Growth and differentiation of neural cells in defined media. In: Cell culture in the neurosciences (Bottenstein J, Sato G, eds), pp 3-43. New York: Plenum.

Braquet P, Touqui L, Shen TY, Vargaftig BB (1987) Perspectives in platelet-activating factor research. Pharmacol Rev 39:97-145.

Bussolino F, Gremo F, Tetta C, Pescarmona G, Camussi G (1986) Production of platelct-activating factor by chick retina. J Biol Chem 261:16502-16508.

Chao CC, Hu S, Molitor TW, Shaskan E, Peterson PK (1992) Activated microglia mediate neuronal cell injury via a nitric oxide mechanism. J Immunol 149:2736-2741.

Clark GD, Happel LT, Zorumski CF, Bazan NG (1992) Enhancement of hippocampal excitatory synaptic transmission by platelet-activating factor. Neuron 9:1211-1216.

Clark JD, Lin L-L, Kriz RW, Ramesha CS, Sultzman LA, Lin AY, Milona N, Knopf JL (1991) A novel arachidonic acid-selective cytosolic PLA contains a $\mathrm{Ca}^{2+}$-dependent translocation domain with homology to PKC and GAP. Cell 65:1043-1051.

Dawson TM, Snyder SH (1994) Gases as biological messengers: nitric oxide and carbon monoxide in the brain. J Neurosci 14:5147-5159.

del Rio-Hortega P (1932) Microglia. In: Cytology and cellular pathology of the nervous system 2. (Penfield W, ed), pp 483-534. New York: Paul B. Hoeber.

Demopoulos CA, Pinckard RN, Hanahan DJ (1979) Platelet-activating factor. Evidence for 1-O-alkyl-2-acctyl-sn-glycerol-3-phosphorylcholine as the active component (a new class of lipid chemical mediators). J Biol Chem 254:9355-9358.

Doucet JP, Bazan NG (1992) Excitable membranes, lipid messengers, and immediate-early genes. Alteration of signal transduction in neuromodulation and neurotrauma. Mol Neurobiol 6:407-424.

Epstein L, Gendelman H (1993) Human immunodeficiency virus type 1 infection of the nervous system: pathogenetic mechanisms. Ann Neurol $33: 429-436$.

Feuerstein G, Yue TL, Lysko PG (1990) Platelet-activating factor. A putative mediator in central nervous system injury? Stroke 21[Suppl III]:90-94.

Frerichs KU, Feuerstein GZ (1990) Platelet-activating factor; key mediator in neuroinjury? Cerebrovase Brain Metab Rev 2:148-160.

Gelbard HA, Noltel HS, Swindells S, Jett M, Dzenko KA, Genis P, White R, Wang L, Choi YB, Zhang D, Lipton SA, Tourtellotte WW, Epstein LG, Gendelman HE (1994) Platelet-activating factor: a candidate human immunodeficiency virus type 1-induced neurotoxin. J Virol 68:4628-4635.

Genis P, Jett M, Bernton EW, Boyle T, Gelbard HA, Dzenko K, Keane RW, Resnick L, Mizrachi Y, Volsky DJ, Epstein LG, Gendelman HE (1992) Cytokines and arachidonic metabolites produced during human immunodeficiency virus (HIV)-infected macrophage-astroglia interactions: implications for the neuropathogenesis of HIV disease. J Exp Med 176:1703-1718.

Gilboe DD, Kintner D, Fitzpatrick JII, Emoto SE, Esanu A, Braquet PG, Bazan NG (1991) Recovery of postischemic brain metabolism and function following treatment with a free radical scavenger and plateletactivating factor antagonists. J Neurochem 56:311-319.

Giulian D, Corpuz M, Chapman S, Mansouri M, Robertson C (1993a) Reactive mononuclear phagocytes release neurotoxins after ischemic and traumatic injury to the central nervous system. J Neurosci Res $36: 681-693$.
Giulian D, Vaca K, Corpuz M (1993b) Brain glia release factors with opposing actions upon neuronal survival. J Neurosci 13:29-37.

Giulian D, Vaca K, Noonan C (1990) Secretion of neurotoxins by mononuclear phagocytes infected with HIV-1. Science 250:1593-1596.

Hanahan DJ (1986) Platelet activating factor: a biologically active phosphoglyceride. Annu Rev Biochem 55:483-509.

I Iattori M, Adachi H, Tsujimoto M, Arai H, Inuue K (1994) MillerDieker lissencephaly gene encodes a subunit of brain platelet-activating factor acetylhydrolase. Nature 370:216-218.

Hayashi H, Kudo I, Nojima S, Inoue K (1991) Biological response of guinea pig peritoneal macrophages to platelet-activating factor. Lipids 26:1193-1199.

Honda Z, Nakamura M, Miki I, Minami M, Watanabe T, Seyama Y, Okado H, Toh H, Ito K, Miyamoto T, Shimizu T (1991) Cloning by functional expression of platelet-activating factor receptor from guineapig lung. Nature 349:342-346.

Honda Z, Takano T, Gotoh Y, Nishida E, Ito K, Shimizu T (1994) Transfcctcd platclct-activating factor receptor activates mitugenactivated protein (MAP) kinase and MAP kinase kinase in Chinese hamster ovary cells. J Biol Chem 269:2307-2315.

Ishii S, Matsuda Y, Nakamura M, Waga I, Kume K, Izumi T, Shimizu T (1996) A murine platelet-activating factor receptor gene: cloning, chromosomal localization and up-regulation of expression by lipopolysaccharide in peritoneal resident macrophages. Biochem J 314:671-678.

Izquierdo I, Fin C, Schmitz P, Da Silvia R, Jerusalinsky D, Quillfeldt J, Ferreira M, Medina J, Bazan N (1995) Memory enhancement by intrahippocampal, intramygdala, or intracntorhinal infusion of plateletactivating factor measured in an inhibitory avoidance task. Proc Natl Acad Aci USA 92:5047 5051.

Izumi T, Shimizu T (1995) Platelet-activating factor receptor: gene expression and signal transduction. Biochim Biophys Actat 1259:317-333.

Kato K, Clark GD, Bazan NG, Zorumski CF (1994) Platclet-activating factor as a potential retrograde messenger in CA1 hippocampal longterm potentiation. Nature 367:175-179.

Kato K, Uruno K, Saito K, Kato H (1991) Both arachidonic acid and 1-oleoyl-2-acetyl glycerol in low magnesium solution induce long-term potentiation in hippocampal CAl neurons in vitro. Brain Res 563:94-100.

Kornecki E, Ehrlich YH (1988) Neuroregulatory and neuropathological actions of the ether-phospholipid platelet-activating factor. Science 240:1792-1794.

Kornecki E, Ehrlich YH (1991) Calcium ion mobilization in neuronal cells induced by PAF. Lipids 26:1243-1246.

Kramer RM, Roberts EF, Manetta J, Putnam JE (1991) The $\mathrm{Ca}^{2+}$. sensitive cytosolic phospholipase $A_{2}$ is a $100 \mathrm{kDa}$ protein in human monoblast UY37 cells. J Biol Chem 266:5268-5272.

Kumar R, Harvey S, Kester M, Hanahan D, Olson M (1988) Production and effects of platelet-activating factor in the rat brain. Biochim Biophys Acta 963:375-383.

Lees G (1993) The possible contribution of microglia and macrophages to delayed neuronal death after ischemia. J Neurol Sci 114:119-122.

Lin L-L, Lin AY, Knopf JL (1992) Cytosolic phospholipase A 2 is coupled to hormonally regulated release of arachidonic acid. Proc Natl Acad Sci USA 89:6147-6151.

Lipton SA (1992) Requirement for macrophages in neuronal injury induced by HIV envelope protein gp 120. NeuroReport 3:913-915.

Lipton SA (1994) Neuronal injury associated with HIV-I and potential treatment with calcium-channel and NMDA antagonists. Dev Neurosci $16: 145-151$.

Lipton SA, Sucher NJ, Kaiser PK, Dreyer EB (1991) Synergistic effects of HIV coat protein and NMDA receptor-mediated neurotoxicity. Neuron 7:111-118.

Lipton SA, Yeh M, Dreyer EB (1994) Update on current models of HIV-related neuronal injury: platelet-activating factor, arachidonic acid and nitric oxide. Adv Neuroimmunol 4:181-188.

MaCarthy K, de Vellis J (1980) Preparation of separate astroglial and oligodendroglial cell cultures from rat cerebral tissue. J Cell Biol 85:890-902.

MacDonald R, Swift G, Przybyla A, Chirgwin J (1987) Isolation of RNA using guanidium salts. Methods Enzymol 152:219-227.

Merrill JE, Ignarro LJ, Sherman MP, Melinek J, Lane TE (1993) Microglial cell cytotoxicity of oligodendrocytes is mediated through nitric oxide. J Immunol 151:2132-2141.

Miller B, Sarantis M, Traynelis SF, Attwell D (1992) Potentiation of NMDA receptor currents by arachidonic acid. Nature 355:722-725. 
Mori T, Iijima N, Kitabatake K, Kohsaka S (1990) Alpha 2-macroglobulin is an astroglia-derived neurite-promoting factor for cultured neurons from rat central nervous system. Brain Res 527:55-61.

Murphy S, Welk G (1990) Hydrolysis of polyphosphoinositides in astrocytes by platelet-activating factor. Eur J Pharmacol 188:399-401.

Mutoh H, Bito H, Minami M, Nakamura M, Honda Z, Izumi T, Nakata R, Kurachi Y, Terano A, Shimizu T (1993) Two different promoters direct expression of two distinct forms of mRNA of human plateletactivating factor receptor. FEBS Lett 322:129-134.

Mutoh H, Fukada T, Masushige S, Sasaki H, Shimizu T, Kato S (1996) Tissue-specific response of the human platelet-activating factor receptor gene to retinoic acid and thyroid hormone by alternative promotor usage. Proc Natl Acad Sci USA 93:774-779.

Mutoh H, Ishii S, Izumi T, Kato S, Shimizu T (1994) Platelet-activating factor (PAF) positively auto-regulates the expression of human PAF receptor transcript 1 (leukocyte-type) through NF- $k$ B. Biochem Biophys Res Commun 205:1137-1142.

Nakajima K, Hamanoue M, Shimojo M, Takei N, Kohsaka S (1989) Characterization of microglia isolated from a primary culture of embryonic rat brain by a simplified method. Biomed Res 10: 411-423.

Nakajima K, Kohsaka S (1993) Functional roles of microglia in the brain. Neurosci Res 17:187-203.

Nakajima K, Shimojo M, Hamanoue M, Ishiura S, Sugita H, Kohsaka S (1992) Identification of elastase as a secretory protease from cultured rat microglia. J Neurochem 58:1401-1408.

Owada Y, Tominaga T, Yoshimoto T, Kondo H (1994) Molecular cloning of rat cDNA for cytosolic phospholipase $A_{2}$ and the inereased gene expression in the dentate gyrus following transient forebrain ischemia. Mol Brain Res 25:364-368.

Panetta T, Marchesclli VL, Braquet P, Bazan NG (1989) Arachidonic acid metabolism and cerebral blood flow in the normal, ischemic, and reperfused gerbil brain. Inhibition of ischemia-reperfusion-induced cerebral injury by a platelet-activating factor antagonist (BN 52021). Ann NY Acad Sci 559:340-351.

Petroni A, Salami M, Blasevich M, Papini N, Galella G, Colombo C, Galli C (1994) Eicosanoid and inositol phosphate response to plateletactivating factor (PAF) and to a PAF antagonist in rat astroglial cells. Brain Res Dev Brain Res 78:169-174.

Piani D, Frei K, Do K, Cuenod M, Fontana A (1991) Murine brain macrophages induce NMDA receptor mediated neurotoxicity in vitro by secreting glutamate. Ncurosci Lett 133:159-162.

Prehn JH, Krieglstein J (1993) Platelet-activating factor antagonists reduce excitotoxic damage in cultured neurons from embryonic chick telencephalon and protect the rat hippocampus and neocortex from ischemic injury in vivo. $\mathbf{J}$ Neurosci Res 34:179-188.

Prescott SM, Zimmerman GA, McIntyre TM (1990) Platelet-activating factor. J Biol Chem 265:17381-17384.

Reiner O, Carrozzo R, Shen Y, Whenert M, Faustinella F, Dobyns W, Caskey C, Ledbetter D (1993) Isolation of a Miller-Dieker lissencephaly gene containing $\mathrm{G}$ protein $\beta$-subunit-like repeats. Nature $364: 717-721$

Rhigi M, Letari O, Sacerdote P, Marangoni F, Miozzo A, Nicosia S (1995) $m y c$-Immortalized microglial cells express a functional plateletactivating factor receptor. J Neurochem 64:121-129.
Ring PC, Seldon PM, Barnes PJ, Giembycz MA (1993) Pharmacological characterization of a receptor for platelet-activating factor on guinea pig peritoneal macrophages using $\left[{ }^{3} \mathrm{H}\right]$ apafant, a selective and competitive platelet-activating factor antagonist: evidence that the noncompetitive behavior of apafant in functional studies relates to slow kinetics of dissociation. Mol Pharmacol 43:302-312.

Saitoh S, Iijima N, Ikeda M, Nakajima K, Kimura M, Katsuki M, Mori T, Kohsaka S (1992) De novo production of $\alpha 2$-macroglobulin in cultured astroglia from rat brain. Mol Brain Res 12:155-161.

Shigemoto R, Nakanishi S, Mizuno M (1992) Distribution of the mRNA for a metabolic glutamate receptor (mGluR1) in the central nervous system: an in situ hybridization study in adult and developing rat J Comp Neurol 322:121-135.

Shimizu T, Wolfe LS (1990) Arachidonic acid cascade and signal transduction. J Neurochem 55:1-15.

Snyder F (1989) Biochemistry of platelet-activating factor: a unique class of biologically active phospholipids. Proc Soc Exp Biol Med 190:125-135

Sogos V, Bussolino F, Pilia E, Torelli S, Gremo F (1990) Acetylcholineinduced production of platelet-activating factor by human fetal brain cclls in culturc. J Neurosei Res 27:706-711.

Squinto S, Block A, Braquet P, Bazan N (1989) Platelet-activating factor stimulates Fos/Jun/AP-1 transcription signaling system in human neuroblastoma cells. J Neurosci Res 24:558-566.

Stephenson DT, Manetta JV, White DL, Chiou XG, Cox L, Gitter B, May PC, Sharp JD, Kramer RM, Clemens JA (1994) Calcium-sensitive cytosolic phospholipasc $\mathrm{A}_{2}\left(\mathrm{cPLA}_{2}\right)$ is expressed in human brain astrocytes. Brain Res 637:97-105.

Takei N, Kondo J, Nagaike K, Ohsawa K, Kato K, Kohsaka S (1991) Neuronal survival factor from bovine brain is identical to neuronspecific enolase. J Neurochem 57:1178-1184.

Thomas W (1992) Brain macrophage: evaluation of microglia and the functions. Brain Res Rev 17:21-74.

Vaughan DW (1984) The structure of neuroglial cells. In: Cerebral cortex 2 (Jones EG, Peters A, eds), pp 285-32\%. New York: Plenum.

Volterra A, Trotti D, Cassutti P, Tromba C, Salvaggio A, Melcangi RC, Racagni G (1992) High sensitivity of glutamate uptake to extracellular arachidonic acid levels in rat cortical synaptosomes and astrocytes. J Neurochem 59:600-606.

Wieraszko A, Li G, Kornecki E, Hogan MV, Ehrlich YH (1993) Longterm potentiation in the hippocampus induced by platelet-activating factor. Neuron 10:553-557.

Willard AL (1992) Excitatory and neurotoxic actions of plateletactivating factor on rat myenteric neurons in cell culture. Ann NY Acad Sci 664:284-292.

Williams JH, Errington ML, Lynch MA, Bliss TV (1989) Arachidonic acid induces a long-term activity-dependent enhancement of synaptic transmission in the hippocampus. Nature 341:739-742.

Yue TL, Stadel JM, Sarau HM, Friedman E, Gu JL, Powers DA, Gleason MM, Feuerstein G, Wang HY (1992) Platelet-activating factor stimulates phosphoinositide turnover in neurohybrid NCB-20 cells: involvement of pertussis toxin-sensitive guanine nucleotide-binding proteins and inhibition by protein kinase C. Mol Pharmacol 41:281-289. 